\title{
Phraseological Units of Greek Origin in Albanian Spoken Language
}

\author{
Sofia Delijorgji, Ph.D \\ Department of Greek Language, Faculty of Foreign Languages, \\ University of Tirana, Tirana, Albania \\ Maklena Nika, Ph.D \\ Department of Greek Language, Faculty of Foreign Languages, \\ University of Tirana, Tirana, Albania
}

\section{Doi:10.5901/mjss.2014.v5n1p635}

\section{Abstract}

This research was conducted to note that Albanian and Greek languages have always imported and exported from one another. The close give-and-take relation of Albanian and Greek can be noticed in the field of phraseology amongst others. The phraseological units are produced and used in the spoken and written language to meet the needs of the society in relation to the function of language as a means of communication and they own the most salient features in every language. The microsystems of the Greek and Albanian phraseological units have specific features of their own in terms of semantics and structure, sources, frequency of usage, the history and geography of usage, stylistic reference, their word-building and lexicalization ability, etc. They are divided in two groups: the group of calque phraseological units as literally translated from Greek into Albanian and the group of calque phraseological units not literally translated from Greek into Albanian. Also, there are various ways and sources of the origin of phraseological units in the Greek language. Some phraseological units derived from the rich and ancient Greek mythology, some others have their source from the Bible, some others derived from philosophy, literature, etc. and some are associated with geography, history. The last important issue to be dwelled on is the existence of hundreds and thousands of parallel phraseological units of the same semantics and the same or almost the same lexical structure in both languages, which are to be found even in a wider geographical territory in the Balkans.

\section{Introduction}

Greek and Albanian have been in a language contact situation for millennia. It is worth noting that Albanian language is the offspring of the Southern llirian language, therefore the contact language situation has existed not only within the time framework of 1500 years where Albanian language acquired the status of a special language, but even beyond that for longer centuries. They have always imported and exported from one another despite the status they have enjoyed. It is a well-known fact that the Greek language has had a very long tradition of writing. It was the official language in the Byzantine Empire for centuries and owing to its richness and potential has greatly contributed to many languages of the Indo-European family of languages, especially in terms of terminology.

The close give-and-take relation of Albanian and Greek can be noticed in the field of phraseology amongst others. The phraseological units are produced and used in the spoken and written language to meet the needs of the society in relation to the function of language as a means of communication and they own the most salient features in every language. They reveal the national character of the semantic and lexical richness of the language much more explicitly than the other lexical units and at greater length.

The microsystems of the Greek and Albanian phraseological units have specific features of their own in terms of semantics and structure, sources, frequency of usage, the history and geography of usage, stylistic reference, their wordbuilding and lexicalization ability, etc.

\section{Influences and Determinations}

Before investigating the influence of the phraseological units of Greek origin in the Albanian language, the loaning nature of Greek and the receiving nature of Albanian, we hold important to bring some theoretical accounts which have influenced and determined our practice of work 
a. There is a certain divergence of opinion among semantologists, leksicologists, lexicographists and phraseologists about the concept of the phraseological units although phraseology has been much treated and for a long period of time. Phraseology has been conceived as a microsystem of no clear-cut borders despite the specifics of the phraseological units of a particular language.

Overall, phraseological units are defined as word groups of relative stability, reproduced in speech as readymade units, being highly expressive and having a particular meaning of their own. This definition implies that the essential feature of these linguistic units is idiomaticity. But the borderline cases between idiomatic and non-idiomatic word-groups are so numerous and confusing that idiomaticity seems far from easy to be determined. The lists of idioms and phraseological units as compiled by different leksicologists are so diverse and different from one another that in certain cases they seem to exclude one another. Some linguists include all the set phrases in the group of phraseological units, whereas some other linguists include just a specific group of the set phrases. Some other linguists hold quite appropriate to involve even proverbs, figurative expressions, quotations, aphorisms, winged words, etc. which in fact provide different linguistic notions and their terminology is not synonymous to phraseological units.

b. Greek is the language of an ancient culture and as such has developed since early the expectation of a great and wide usage of phraseology. It has acquired a developed system of phraseological units of different stylistic connotations. In this article, we have dealt with phraseology by relying on the different theoretical views all over the world but mostly on the theoretical views on phraseology in the Albanian language rather than on those of Greek language. The reason counting for this is that Albanian language in comparison with other languages is very rich in phraseological units and has enjoyed a valuable tradition of phraseography. Meanwhile not only doesn't the Greek language possess a specific dictionary of phraseological units, but the research work on the theoretical lexico-semantic aspects of phraseology, wise sayings, winged words and quotes has reached no levels as those of Russian, English, Italian, French, etc. despite its being one of the oldest languages in the Indo-European family of languages and having high degrees of refinement.

The most essential feature of phraseological units is meaning, its nature and the way it was formed and these have contributed to the stability, inseparability, and semantic, grammatical and functional unity of phraseological units. We have come to accept the assumption that almost all phraseological units can be traced back to free word-groups which in the course of the historical development of a language have undergone the long and beautiful process of gradual semantic transformation, and thus acquiring a figurative meaning, semantic and grammatical inseparability and being reproduced in speech as readymade units, the most distinguishing feature of all being the lexicalized figurative meaning. Jani Thomai analyses that "the partial or complete morphological stability of the component lexemes of the word-group, semantic unity and inseparability, the non-motivation of the component lexemes of the word-group and their re-motivation (as they get transformed and perceived as an independent separate functional linguistic unit equivalent to the word), different syntactic functions, the highly emotive charge, the semantic and word-building development, etc. can be evidenced as some of the features of this transformation".

c. Based on these views, this article elaborates on cases of phraseological units which are functionally equivalent to words, putting aside proverbs, saying, aphorisms, winged words, etc. despite their figurative meaning. Many units we are analyzing can be traced back to these winged words, which are today used as single words, not as quotations or extracted sentences.

\section{Albanian Language and Phraseological Units}

As already mentioned, Albanian language owns a very rich phraseology and it is very active and prolific in the process of the coinage of phraseological units even nowadays. Jani Thomai is the most well-known Albanian researcher on the richness of Albanian phraseological units and has compiled a dictionary of them. He has elaborated on their sources and origins. Here we are setting forth some of his views:

- First of all, the origin of "the major part of Albanian phraseological units is to be traced in the patterns of Albanian folk discourse where they were coined. They were born, processed and refined in the Albanian spoken language".

- Secondly, "Albanian language owns loan phraseological units, which do not constitute an important part of its phraseology". Just a limited number of loan phraseological units have not been assimilated and are thus nonmotivated. They have made their way into Albanian lexicon as international set phrases (formula), deriving 
mostly from Latin or Neo-Latin languages, confined in their usage in certain stylistic layers: casus belli, honoris causa, modus vivendi, mot a mot, salto mortale ..."

- Thirdly, "the most important part of the phraseological units is to be occupied by the loan translation phraseological units (calques), i.e. phraseological units of foreign language origin being literally translated into Albanian: me bën përshtypje, (it impresses me), hauret e Augjiasit, i hedh hije, ka vend, kullë e fildishtë, marr masa (take measures), marr pjesë (take part), troket në derë të hapur, thyej akullin (break the ice), vë pikën mbi i (to dot one's i's)...".

Albanian language makes use of linguistic units closely connected to Greek phraseology and we are going to draw the attention on the paradigmatic groups which are calques or quasi-calques by design. If these calques have been incorporated in the vocabulary, then the process of the figurative transformation of the word-groups which has occurred in the Greek language has not similarly occurred in Albanian and this means "the creation and coinage of word-groups of different typology within the framework of a sentence, the syntagmatic lexical relations of words as conditioned by linguistic and extra-linguistic factors which constitute the basis of the figurative transformation of the word-group". This is a three-level process: free word-group - "prepared" word-group - phraseological unit.

\section{Subdivision of Paradigmatic Groups}

According to a general taxonomy concept, this paradigmatic group can be classified into two major ones which can be further subdivided into more subgroups:

a. The group of calque phraseological units as literally translated from Greek into Albanian. In their composition there are two or more notional words of general usage, e.g. mollë sherri (apple of discord), etc. The loan and calque phraseological units are mostly devoid of emotive charge and are used in cultivated language, in the stylistic layers of the language of science, the language of political and social field, media, journalism, etc. Some of the calques form couplets, e.g. in Albanian there exists the calque phraseological unit nga alfa tek omega (from alpha to omega) which reflects a partial calquing process and thus preserving a direct connection with the Greek phraseological unit. In addition to that, there exists the phraseological unit nga a-ja tek zh-ja (from A to Z) which reflects a complete calquing process.

b. The group of calque phraseological units not literally translated from Greek into Albanian. There are two or more notional words in the composition of these phraseological units, one of which is of general usage and the other is a proper noun closely connected to Greek mythology, history, philosophy, politics, culture, literature, etc. e.g. molla e Adamit (Adam's apple), guri i Sizifit (the stone of Sisyphus), vuajtjet e Tantalit (the pains of Tantalus), etc.

Some of these phraseological units such as molla e Adamit (Adam's apple, in other words in Albanian fikthi), kompleksi i Edipit (Edipus complex) etc. emerge as not quite simple phrases in different fields of human knowledge and science. Considering the inner semantic development of their structure, they have been determined as nominal phraseological units by Jani Thomai and this brings again under discussion the notion of the phraseological units.

Many phraseological units of the written language nature which are of either Greek origin or the origin of some other languages that have an international status have made their way into the Albanian language through Greek directly or indirectly. These phraseological units have made their way into spoken Albanian as well, partly as a result of the influence that journalism exerts. The phraseological units have crystallized the mythological mentality and the rich historical experience of the Greek people, the daily activities, the lifestyle and the culture of these people in them. The loaning process of the phraseological units into the Albania language demonstrates the existence of common things between the two peoples.

\section{Origin of Phraseological Units in Albanian}

There are various ways and sources of the origin of phraseological units in the Albanian language:

a. Some phraseological units derived from the rich and ancient Greek mythology: pastroj ahuret (stallat) e Augjias), filli i Arianës, flet nga maja e Olimpit, si gosti në Olimp, pëlhura e Penelopës, kutia e Pandorës, zjarri i Prometeut, bashka e artë, shpata e Damokleut, thembra e Akilit, kalë Troje, midis Skillës dhe Karibdës, dhurata e danajve, feneri i Diogjenit, fuçia e Diogjenit, mundimet e Tantalit, frutat e Tantalit, guri i Sizifit, kompleksi i Edipit, fluturimi i lkarit, nyja gordiane, kaloj Akerontin, ka veshet e Midasit, kthehem në Itakë, mollë sherri, kapërceu shtyllat e Herkulit, etc. 
b. Another important source is the Bible: gjykimi i Solomonit, si Shën Thomai mosbesues, gomari i Balamit, molla e Adamit, mollë e ndaluar, pesha e kryqit, udha e kryqit, toka e premtuar, arka e Noes, ardhja e dytë, ka humbur biblën, gjethe fiku, si kopshti i Edenit, qengji i Perëndisë etj.

c. Some other phraseological units derived from philosophy, literature, etc.: nga alfa te omega, alfa dhe omega, fluturim pindarik, dashuri platonike, ironi sokratike, gjithçka rrjedh, i thur ditirambe, kohë e artë etc.

d. Some are associated with geography, history: fitore e Pirros; këtu është Rodi, këtu kërce; si beteja e Termopileve; vrapim Maratone, etc.

\section{Parallel Phraseologic Units}

The last important issue to be dwelled on is the existence of hundreds and thousands of parallel phraseological units of the same semantics and the same or almost the same lexical structure in both languages, which are to be found even in a wider geographical territory in the Balkans. It is not appropriate to consider the receiving or loaning nature of the Greek and Albanian languages in this case, but we support the view held in the Preface of the Phraseological units in the Balkans (Tiranë, 1999) that in the language set of the Balkans created in a historically ancient territory where the coexistence of peoples has brought many typological features of their languages into convergence and according to the research work of Sanfeldi, Çabej, etc. there have emerged 400-500 parallel phraseological units, but the authors of the dictionary hold that the riches of phraseology can be ten times more the figure mentioned. There phraseological units derived from the folk discourse of the people and are associated with their different material and spiritual world. Many non-linguistic factors, such as geo-historical, psychological, economic, ethno-cultural, mythological, etc. factors have influenced in coining them.

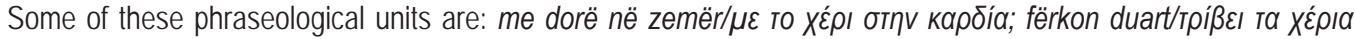

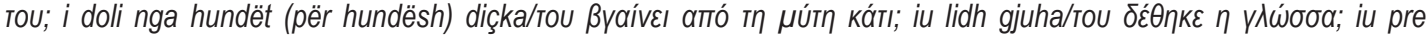

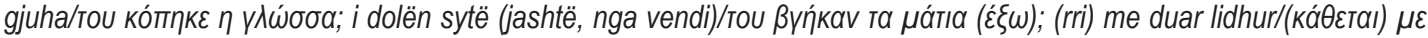

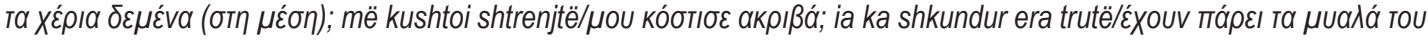

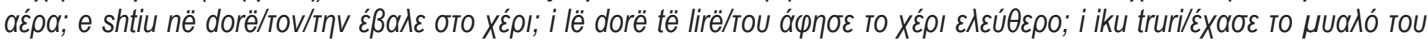

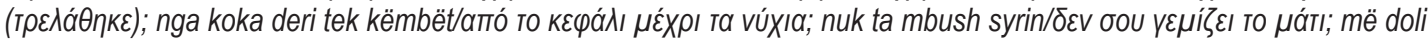

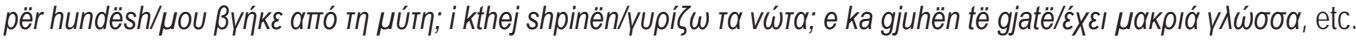

The phraseological units belonging to this group are nominal, adjectival, verbal and adverbial phrases in both languages and they are formed in the same ways on the basis of simile, metaphor, hyperbole, personification, synecdoche, metonymy, analogy, etc.

\section{Concluding Remarks}

Considering the location of Greece in the south of Albania, it is clear that the best Greek influence in the lexis, semantics and phraseology of the Albanian language is found in the regions where contact with the Greek language is more frequent and easier i.e. in the border and tosk dialect. It is worth emphasizing that the isomorphic nature of the denominations (although most of them behave as terms) and phraseological units we covered (and all their denominative, expressive, emotive and stylistic values) reveal that by having knowledge and making use of them not only are the geographical, regional and dialect borders crossed, but even the social borders within the Albanian society. These words and phraseological units are getting used not only by the educated class, but by all the people at large. The emigration and the great language and cultural interactions between the two peoples count for this.

The knowledge of the phraseological richness in both languages constitutes the most important link in the language acquisition and points to the level of emancipation and cultural integrity. Their appropriate usage is very important in the information transmission among people and enriches the discourse by making it more diverse, figurative, expressive and beautiful.

In the last two decades, the language contacts between Albanians and Greeks have been intensified immensely. The economic, social, political, cultural, scientific factors, etc. have contributed and conditioned this interaction. In their verbal communication, problems do arise as to a proper performance and command of Greek by Albanians or a good command of Albanian by Greeks. Their acquisition and good performance in these languages are due to not only their profession and specialization in languages, but many other linguistic and non-linguistic factors count for situation created some of which are the level of development and cultivation of the language, the level of education and knowledge of the language lexicon. The usage of phraseological units makes the spoken and written language more lively, versatile, 
attractive and eases the process of acquisition at schools, the daily discourses, translation and interpretation in all fields of life and the research work on lexicography.

\section{References}

A. Jashari, Fjalor me shprehje të huazuara në gjuhën shqipe, Korçë 2007, Preface

E. Çabej. Studime gjuhësore, Prishtinë, 1977

J. Thomai, Leksikologjia e gjuhës shqipe , Tiranë, 1999:186, 255

J. Thomai, Leksikologjia e gjuhës shqipe, Tiranë, 2008: 255

J. Thomai, Xh. Lloshi, R. Hristova. K. Qiriazati and A. Melonashi , Fjalori frazeologjik ballkanik (shqip - bullgarisht - greqisht- rumanisht serbokroatisht). Tiranë, 1999

M.I. Fomina, Gjuha e sotme ruse: Leksikologjia, Moskë 1990

Sh. Demiraj, Gjuha shqipe dhe historia e saj, Tiranë, 1989

V. Memisha, Rreth shndërrimit të togfjalëshve të lirë në njësi frazeologjike, SF. 3-4, 2006:113

V. Memisha, Termat togfjalësha në fjalorët shpjegues të shqipes in the Scientific Conference "Gjendja dhe zhvillimi i terminologjisë shqipe, probleme e detyra", Tiranë, 2009

V. Memisha, Participial Adjectives in Albanian and in Greek, in Albanohellenica, 3, Athens, 2008 
